\title{
DOI: https://doi.org/10.24297/jaa.v10i0.8308
}

\section{Distribution, Impacts and Management Option for Water Hyacinth (Eichhnornia Crassipes [Mart.] Solms) in Ethiopia: A Review}

\author{
Yigrem Mengist* and Yohannes Moges
}

Department of Plant Sciences, College of Agriculture and Environmental Sciences, University of Gondar, P. O. Box 196, Gondar, Ethiopia

yigermmengist07@gmail.com

\begin{abstract}
Water hyacinth (Eichhprnia crassipes) is the most dangerous and worst invasive aquatic weed in the worldwide including Ethiopia, and negatively affecting millions of water resources, fisheries, transportation and social structure. Water hyacinth was introduced in the water bodies of the Rift Valley in 68years ago and currently, the weed is distributed Lake Tana, Lake Abaya, Lake Koka, Koka Dam. The wide distribution and abundance of water hyacinth has led to decreased water availability and sustainable water biodiversity in Ethiopian lakes. However, the spread of water hyacinth is threatening not only water biodiversity but also socioeconomic development and human wellbeing. Water hyacinth in water bodies and nearby areas the local stakeholder has its negative impact on environmental problem and it's influenced aquatics biodiversity. This review paper aimed to investigate the distribution, impacts and its integrated management option against water hyacinth in Ethiopia. Therefore, based on the review it can be concluded that human intervention is considered as the current problem of water resource in the country and further study is needed to sustain the water resource are needed to keep water hyacinth at unproblematic levels.
\end{abstract}

Keywords: Eichhornia Crassipes, Water Hyacinth, Biological Control, Invasive Weed, Integrated Management

\section{Introduction}

Water hyacinth (Eichhornia crassipes) is a free floating perennial (or hydrophyte) aquatic weed and one of the major challenging problems in water bodies of the tropics and sub-tropics which originated from the Amazon Basin and has dispersed very rapidly in many countries of Latin America, Africa, Southeast Asia and Pacific in 1950 [1]. International Union for Conservation of Nature (IUCN) lists these species as one of the 100 most dangerous invasive species and as the top ten worst weeds in the world [1]. It is characterized by wide spreading competences, extensive dispersal mechanism, rapid reproductive potential and harsh environment tolerance adaptability [2].

The water hyacinth was officially appeared in Ethiopia about 53 years ago in 1965 at koka reservoir and in the Awash River. Other infestation in the country include Gambela Region, the Blue Nile from just below Lake Tana into Sudan, and Lake Ellen near Alem Tena [3,4]. Water hyacinth caused wastage of water through excessive evapotranspiration, recreational use of aquatic ecosystem, and poses of mechanical damage to hydroelectric systems. It is also responsible for drastic changes in the fisheries communities of water environments and acts as an agent for the spread of serious diseases in water bodies $[5,6]$. Presently the impact of water hyacinth in Ethiopia have not been estimated yet. However, wonji-shoa sugar estate which estimated about 100,000US\$ from 2005 to 2015 for the control of these weed [7].

An action-implemented management program which involving mechanical, manual and chemical measures was integrated. Although in some of the infested areas these management practice were implemented, the spread of water hyacinth in the rift valley of Ethiopia was continued $[3,8]$. Despite the presence of effective weevil and highly virulent fungal pathogen against water hyacinth, none of them have been utilized to control this invasive weed in Ethiopia up till now [9]. For effective management of water hyacinth, there is need for integrated use of 
mechanical, manual and biological control approaches. However, to gauge the severity of the problem, reliable estimates of water hyacinth distribution and abundance are required. Therefore, the purpose of this review paper is aimed to review in-depth the distribution and impacts of water hyacinth in Ethiopia and suggests the main integrated management approaches which can be adapted for sustainable management.

\section{Occurrence and Distribution of Water Hyacinth}

Water hyacinth is found across the tropical and subtropical region which was originated from Amazon Basin and South America. However, it disseminate very rapidly across in worldwide including Ethiopia [10]. Since the end of $19^{\text {th }}$ century, water hyacinth weed have been disseminated from its origin to all parts of the world as ornamental landscape gardens plant Later on, it has been found in to river, dams, reservoirs, lakes, irrigation and drainage canals throughout in worldwide and became an invasive exotic weed But things got out of control; the water hyacinth was like tiger let out of its cage [11]. Similarly, in Ethiopia these invasive weeds were appeared about 53 years ago in Koka Lake and in the Awash River. Large scale infestation was manifested in many water bodies of Ethiopia like Lake Tana, Lake Abaya, and Lake Ellen; in irrigation canal, drainage structure of the Wonjishoa and Metahara sugar estates located around the Awash River [3, 12].

\section{Biology and Ecology of Water Hyacinth}

Water hyacinth is a perennial, permanent, free floating or anchor in low water, herbaceous and marine aquatic plant species. Even though genes Eichhorania have a number of aquatic species, only Eichhornia crasspes has become a serious weed [13]. Water hyacinth is fresh water plant. It is free floating gets anchored in low water levels. The mature water hyacinth consists of roots, stolons, rhizomes, leaves, inflorescence and fruit cluster. Seeds sink following release from the seed capsule and may subsequently germinate as water levels change and many remain viable for 5 to 20 years [14]. Water hyacinth seeds germinate in backwater areas, in ditches and channels, and in other moist habitats. The seedlings develop into plants with their own leaves and root systems within 40days after germination. Sometimes, the plants get detached from the mud and become free floating. Vegetative reproduction is a common form of propagation and is largely responsible for the rapid increase and spread of water hyacinth into new areas [14].

\section{Impact Posed by Water Hyacinth}

\section{Social Impact}

Water hyacinth highly interfere agricultural practice by blocking irrigation canal and drainage structure and by increasing the loss of water through evapotranspiration. Large water hyacinth mats prevent the transfer of oxygen from the air to the water surface, or decrease oxygen production by other plants and algae [15]. Dissolved oxygen levels can reach dangerously low concentration for fish production that are sensitive to such changes [1]. Furthermore, low dissolved oxygen catalyze the release of phosphorous from the sediment which accelerates eutrophication and can lead to a subsequent increase in water hyacinth or algal blooms [16]. Death and decay of water hyacinth vegetation in large masses deteriorate water quality and the quantity of potable water, and increase treatment costs for drinking water $[1,17]$.

The stagnant water resulting from obstructing effect of water hyacinth provides a breeding ground and a habitat for several vectors disease such as mosquitoes, flies and other organisms associated with human illnesses, including malaria, schistosomiasis and cholera [18]. According to Senayit [19] reported that an increase malaria incidence and lack of drinking water, whereas during peak infestation period the free floating weed serve as an alternate host for snakes and crocodile. Moreover, when the water level decrease, the unpleasant smell from decomposing water hyacinth. It also impedes the recreational use of river and lakes [20]. At the local level increase the incidence of the crocodile attacks have been attributed to the heavy infestation of weed which provides cover to the reptile and poisonous snakes $[1,16]$. 


\section{Economic Impact}

Many large hydropower schemes are suffering from the effect of water hyacinth. It often clogs waterways due to its rapid reproduction and propagation rate. The dense mats of water hyacinth disrupt socioeconomic and subsistence activities [1, 17]. The floating mat limit access to breeding and feeding grounds for some economically important fish species. For example, in Lake Victoria, fish catch was decreased by $45 \%$ because water hyacinth mats blocked access to fishing grounds, delayed access to markets and increased costs of fishing [21].

The current fish production in Lake Tana has declined due to the impact of this weed it had blocked many fishing grounds. According to Wassie [22] reported that water hyacinth infestation has been covered about 34,500 ha. Consequently, all fishers changed their landing site because of water hyacinth expansion obstructs their fishing activities [23]. Therefore, is the expansion of water hyacinth increase in this trend, it can be negatively influencing the local community of fishers by increasing costs of fishing and reduce the amount of fish caught in lake Tana [24]. The fish production potential is estimated for 51,500 tons per year in Ethiopia. However, only $30-38 \%$ of this potential is currently used [25].

According to Pysek and Richardson [26] reported that substantial invasion it reasons very serious disturbance to commercial fishing, boat transport, infrastructure and hydro electricity generation. Under heavy infestation of water hyacinth the socioeconomic structure, food supply and healthy of the societies exists around the lake are extremely worried [27]. In connection to this, a high infestation level of water hyacinth was also reported in some other Ethiopian rift valley lakes mainly in Aba Samuel Dam, Lake Ellen, Lake Koka and Lake Wonji Firehun et.al., [15] studies revealed that a rapid increase in water hyacinth was observed time to time.

As a result, the reduction of large barbs has been observed presently in Lake Tana, which has got shallower and shallower due to water hyacinth. For example, Koka hydro power dam in Ethiopia suffer from rapid reduction of water resource due to water hyacinth problem [28]. High infestation of this weed restrict water flow in river and irrigation channels and cause structural bridge damage [29]. Reduced irrigation flow can cause indirectly loss on field crops[1]. In Ethiopia, water hyacinth caused wastage of water through excessive evapotranspiration [28]. Besides, the drainage system blockage by the weed contributes for the rise of groundwater table and flooding problems.

\section{Environmental Impact}

Water hyacinth mats block irrigation canal and rivers leading to flooding. Once it disseminates very rapidly in a water bodies, the weed drastically changes water biodiversity and this often results environmental degradation and disturb water ecosystem. The blockage of waterways by water hyacinth encourage siltation problem and reduce activities like swimming, fishing and sand extraction from lakes or rivers [20]. The weed may negatively affect some native species of invertebrate, fish, birds and beneficial algae. Recent finding reported that a massive reduction of fish production due to reduce oxygen availability, which was attributed to resurgence of the weed [30]. The weed out-compute the native species which live in the water body due to its rapid dispersal and reproductive capacity which poses a threat to aquatic ecosystem. Due to its faster colonization, the weed also prevents the growth of essential phytoplankton and which have ultimate negatively effects on fisheries and other vital aquatic animals.

Water hyacinth have a series consequence of death of fish from oxygen poisons, amplified carbon dioxide and low oxygen meditation at evening and diminution of the oxygen due to breakdown of the departed biomass of algae and phytoplankton. The enlarged water hyacinth invasion has, therefore obstructed negatively on the water quantity and quality, electric power generation, fishing activities, transportation, drinking for human and other animals, plankton life, and recreational health. Rapid dispersal rate and abundance on the large water bodies is causing different problem [31]. This weed also affects solar light penetration into water bodies, reduce oxygen level through decomposition, alter chemistry of water and substantial loss of water through evapo transpiration $[4,27]$. 


\section{Management of Water Hyacinth}

Water hyacinth management is not cheaper but it is much easier and cheaper to manage weed establishment when small weed infestation is treated quickly. Currently, water hyacinth control is absolutely essential. Worldwide finding reported that different management approaches has been implemented for the management of water hyacinth. In most cases the best management approach combines manual, physical, mechanical, biological and use of herbicides [32]. However, the existing management methods have often insufficient to control invasive weed of water hyacinth [27], mainly due to lack of continued policy and management support by governments.

\section{Mechanical Control}

Water hyacinth removal by hand machine is a practical control method often used for small areas or when numbers are low. Physical removal is most effective for small infestation and should be made before flowering and seed set. Mechanical control of water hyacinth can help take advantage of flooding or water flush that deposit water hyacinth in dams and calm water areas of rivers. When using this approach, it is essential water hyacinth is removed before its rapid growth commences. Mechanical control operation are commons in Ethiopian lakes and rivers. However, regrowth of the chopped weed is likely to take place, especially if the natural enemies are not well protected during chopping. In addition, shallow area of the lake and river are likely to fill up with vegetation especially along the shoreline, leading to subsequent reduction in size of lake and river.

\section{Chemical Control}

Chemical control is other option. Public opinion all over the world is against the use of herbicides in water biodiversity, but the use of herbicides seems to be unavoidable in certain circumstance and, if they are applied properly and with caution environmental problem can be avoided. In addition to environmental concern, another constraint is the need to purchase simple spraying equipment to be mounted in a boat to apply the herbicide on water bodies [33]. Among the herbicides glyphosate is safest for use in water body, however, cost of application (no less than US\$28/ha) would be prohibited in some countries [10,34]. Another option is 2-4-D, seems to be safe for fish, and is rapidly degraded in the environment and much cheaper than glyphosate. Application of any of these herbicides should be made in specific infested sites, but never in overall application to the whole infested area to avoid the depletion of water oxygen availability due to incorporation into the water of the destroyed water hyacinth mass. [18] reported that it is most excellent for little invasion area not big areas. Apart from the three control methods, Harley et al. [8] recommended to if the amount of nutrients incoming any water body is decrease, this repetitively reduce the invasion and expansion of the water hyacinth.

\section{Biological Control}

Biological control is most effective on large area of water hyacinth but it may take many years to achieve satisfactory control. Currently due to financial and environmental degradation associated with chemical control actions and their negative factors has increase led to use of biological control measures. Researches into implement of biological control approach was initiated in 57 years ago by United state Department of Agriculture and to date seven arthropods, that disturb water hyacinth in its origin have been released for bio control in many countries [35]. Presently, findings reported that application of biological natural enemies for the control of water hyacinth is the most effective, economical and sustainable control methods as the control persists for long time with little ongoing cost and without environmental impact [9]. In Ethiopia, although the control of water hyacinth by using biological control agent still is not beyond experimental stage, the use of biocontrol agent at the national level has received attention and researchers have become engaged in surveys and evaluate classical and native biocontrol agents [9,36]. According to Firehun [9] reported that the application of fungal pathogen for the control of water hyacinth showed 11-67, 22-72, 15-55 and 12-50\% reduction in fresh weight, dry weight, plant height and root length of water hyacinth, respectively. 
Although many biological control agents such as insects, pathogens, mites, snails, ducks, geese, swans, manatees and fish using plant pathogen and insect has been shown to be highly effective against water hyacinth. Among the known pathogens are Acremonium zonatum, Alternaria alternate, Alternaria eichhorniae, Bipolaris spp, Fusarium chlamydosporum, Helminthosporum, Myrothecium roridum, Rhizoctonia solani and Uredo eichhorniae $[10,37,38]$. These fungi are easy and inexpensive to produce and therefore have potential for development as bio herbicide. Of these fungi Alternaria eichhorniae, Cercospora rodomanii and Fusarium chlamydosporum have been studied to a significant extent. Among insect pests the mite (Orthogalumna terebrantis), the moths Acigona infusella and Sameodes albiguttalis) and weevil (Neochetina eichhorniae and Neochetina bruchi) are generally considered as good candidates for control of water hyacinth [39, 40]. The Chevron weevil (Neochetina bruchi Hustache) and The mottled weevil (Neochetina eichhorniae Warner) and two water hyacinth insect moth species Xubida infusella and Niphograpta albiguttalis are the most successful bio control agents which control of water hyacinth weed released worldwide so far $[27,40]$.

\section{Integrated Management Approach}

Integrated control of water hyacinth is a sensible approach that includes the combination of mechanical, biological and chemical methods that complement each other. Because of rapid dispersal habit of water hyacinth and among practical constraint and financial cost associated with physical, mechanical, biological and chemical control measures alone are not effective for the control of water hyacinth. Thus, integrated managements that stress the weeds over a longer period of time are usually required for effective control particularly for established infestation. To sustainably manage the abundance of water hyacinth weed; an advance integrated weed management approach is very essential, where manual, mechanical, biological and herbicides are being jointly implemented [8].

\section{Conclusion}

Water hyacinth abundance in worldwide has been manifested on large scale in many water ecosystems including Ethiopia. It has had a negative social, environmental and ecological impact. The major influencing negative factors include; hindrance to water transport, blockage of irrigation canals and rivers, disrupting of electric power operation, increase loss of water due to evapotranspiration, causing flooding and human health problem, interference fishing activities, navigation, irrigation, livestock watering, and reduction of water biodiversity. Currently findings reported that the use of bio control agent is the most effective, economical and sustainable management approach for water hyacinth. In Ethiopia management of this invasive weed is still under a trial stage. However, the use of biological control agent to reduce the level of water hyacinth at the national level has received a big attention and researchers have become engaged in conducting research. Generally based on the review it can be conclude that human intervention is considered as the current problem of water biodiversity in the country and further investigation is needed to sustain natural biodiversity.

\section{Availability of data and materials}

Please contact the corresponding authors for data request

\section{Conflict of interest}

The authors declare that they have no conflict of interest

\section{Funding Statement}

No funding was received toward this review. 


\section{Acknowledgement}

The authors highly acknowledgement to University of Gondar particularly College of Agriculture and Environmental Sciences for providing all the necessarily materials.

\section{Reference}

1. Patel S: Threats, management and envisaged utilizations of aquatic weed Eichhornia crassipes: an overview. Reviews in Environmental Science and Bio/Technology 2012, 11:249-259.

2. Zhang YY, Zhang DY, Barrett SC: Genetic uniformity characterizes the invasive spread of water hyacinth (Eichhornia crassipes), a clonal aquatic plant. Molecular ecology 2010, 19:1774-1786.

3. Taye $T$, Rezene F, Firehun $\mathrm{Y}$, Derje $\mathrm{T}$, Tamado $\mathrm{T}$ : Review invasive weed research in Ethiopia. Increasing crop production through improved plant protection 2009, 2:381-407.

4. Fessehaie R: Water hyacinth (Eichhornia crassipes): A Review of its weed status in Ethiopia. Arem (Ethiopia) 2005.

5. Admas A, Sahle S, Belete E, Agidie A, Alebachew M: Controlling water hyacinth in lake tana using biological method at green house and pond level. Eur Exp Biol 2017, 7:30.

6. Balmford A, Bond W: Trends in the state of nature and their implications for human well-being. Ecology Letters 2005, 8:1218-1234.

7. Yirefu F, Struik P, Lantinga E, Tessema T: Occurrence and diversity of fungal pathogens associated with water hyacinth and their potential as biocontrol agents in the Rift Valley of Ethiopia. International Journal of Pest Management 2017, 63:355-363.

8. Afework D: Efficacy of integrated water hyacinth (Eichhornia crassipes [mart] solms) management strategies at wonji-shoa sugar factory. Ambo university college, 2008.

9. Firehun $Y$, Struik $P$, Lantinga $E$, Taye $T$ : Joint use of insects and fungal pathogens in the management of waterhyacinth (Eichhornia crassipes): Perspectives for Ethiopia. J Aquat Plant Manage 2013, 51.

10. Dagno K, Lahlali R, Diourte M, Jijakli H: Fungi occurring on waterhyacinth (Eichhornia crassipes (Martius) Solms-Laubach) in Niger River in Mali and their evaluation as mycoherbicides. Journal of Aquatic Plant Management 2012, 50:25-32.

11. Tegene $\mathrm{S}$, Ayele N: Prevalence and intensity of water hyacinth infestation in the water bodies of Rift Valley, Ethiopia. The Journal of Agriculture and Natural Resources Science 2014, 1:118-126.

12. Asmare E: Water hyacinth (Eichhornia crassipses) expansion and the fate of fishers around north eastern part of lake tana, ethiopia.

13. Coetzee J, Hill M, Julien M, Center T, Cordo H: Eichhornia crassipes (Mart.) Solms-Laub.(Pontederiaceae). Biological Control of Tropical Weeds using Arthropods Cambridge University Press, New York, NY 2009:183-210.

14. Dagno K, Lahlali R, Diourte M, Jijakli M: Effect of temperature and water activity on spore germination and mycelial growth of three fungal biocontrol agents against water hyacinth (Eichhornia crassipes). Journal of applied microbiology 2011, 110:521-528. 
15. Firehun $\mathrm{Y}$, Struik $\mathrm{P}$, Lantinga E, Taye T: Water hyacinth in the Rift Valley water bodies of Ethiopia: Its distribution, socio-economic importance and management. Management of water hyacinth (Eichhornia crassipes [Mart] Solms) using bioagents in the Rift Valley of Ethiopia 2014:17.

16. Ndimele $\mathrm{P}$, Kumolu-Johnson $\mathrm{C}$, Anetekhai $\mathrm{M}$ : The invasive aquatic macrophyte, water hyacinth (Eichhornia crassipes (Mart.) Solm-Laubach: Pontedericeae): problems and prospects. Research Journal of Environmental Sciences 2011, 5:509-520.

17. Ndimele P: The Effects ofWater Hyacinth (Eichhornia crassipes [Mart.] Solms) Infestation on the PhysicoChemistry, Nutrient and Heavy Metal Content of Badagry Creek and Ologe Lagoon, Lagos, Nigeria. Journal of Environmental Science and Technology 2012, 5:128-136.

18. Firehun Y, Yohannes Z: Evaluation of some herbicides against water hyacinth (Eichhornia crassipes [Mart.] Solms) at Wonji-Shoa. In Proceedings of Ethiopian Sugar Industry Biennial Conference. 2009: 61-68.

19. Senayit R, Agajie T, Taye T, Adefires W, Getu E: Invasive Alien Plant Control and Prevention in Ethiopia. Pilot Surveys and Control Baseline Conditions Report submitted to EARO, Ethiopia and CABI under the PDF B phase of the UNEP GEF Project-Removing Barriers to Invasive Plant Management in Africa EARO, Addis Ababa, Ethiopia 2004.

20. Cho ME, Tifuh J: Quantification of the impacts of water hyacinth on riparian communities in Cameroon and assessment of an appropriate method of control: the case of the Wouri River Basin. 2012.

21. Kateregga E, Sterner T: Lake Victoria fish stocks and the effects of water hyacinth. The Journal of Environment \& Development 2009, 18:62-78.

22. Wassie A, Miwuyelet M, Ayalew W, Dereje T, Woldegebrael W, Addisalem A, Wondie E: Water hyacinth coverage survey report on Lake Tana. technical report series 1. Blue Nile Water Institute: Bahir Dar; 2014.

23. Asmare E: Current Trend of Water Hyacinth Expansion and Its Consequence on the Fisheries around North Eastern Part of Lake Tana. 2017.

24. Beyene EA: Impact of climate change and anthropogenic activities on livelihood of fishing community around Lake Tana, Ethiopia. EC Agriculture 2016, 3:548-557.

25. Kebede MT, Gubale AG: Fishery management problems in Ethiopia: natural and human induced impacts and the conservation challenges. Reviews in Fisheries Science \& Aquaculture 2016, 24:305-313.

26. Pysek P, Richardson DM: Invasive species, environmental change and management, and health. Annual review of environment and resources 2010, 35:25-55.

27. Gichuki J, Omondi R, Boera P, Okorut T, Matano AS, Jembe T, Ofulla A: Water Hyacinth Eichhornia crassipes (Mart.) Solms-Laubach dynamics and succession in the Nyanza Gulf of Lake Victoria (East Africa): implications for water quality and biodiversity conservation. The Scientific World Journal 2012, 2012.

28. Yirefu F, Tafesse A, Gebeyehu T, Tessema T: Distribution, impact and management of water hyacinth at Wonji-Shewa Sugar Factory. Eth J Weed Manag 2007, 1:41-52.

29. Jones RW: The impact on biodiversity, and integrated control, of water hyacinth, Eichhornia crassipes (Martius) Solms-Laubach (Pontederiaceae) on the Lake Nsezi-Nseleni River System. Rhodes University, 2009. 
30. Waithaka E: Impacts of water hyacinth (Eichhornia crassipes) on the fishing communities of Lake Naivasha, Kenya. Journal of Biodiversity Endanger Species 2013, 1:108.

31. Vila M, Espinar JL, Hejda M, Hulme PE, Jarosik V, Maron JL, Pergl J, Schaffner U, Sun Y, Pysek P: Ecological impacts of invasive alien plants: a meta-analysis of their effects on species, communities and ecosystems. Ecology letters 2011, 14:702-708.

32. Malik A: Environmental challenge vis a vis opportunity: the case of water hyacinth. Environment international 2007, 33:122-138.

33. Firehun $Y$, Struik $P$, Lantinga $E$, Taye $T$ : Joint use of insects and fungal pathogens in the management of water hyacinth (Eichhornia crassipes): Perspectives for Ethiopia. J Aquat Plant Manage 2013, 51.

34. Borokoni T, Babalola F: Management of invasive plant species in Nigeria through economic exploitation: lessons from other countries. Management of Biological Invasions 2012, 3:45-55.

35. Tipping PW, Sosa A, Pokorny EN, Foley J, Schmitz DC, Lane JS, Rodgers L, Mccloud L, Livingston-Way P, Cole MS: Release and establishment of Megamelus scutellaris (Hemiptera: Delphacidae) on waterhyacinth in Florida. Florida Entomologist 2014, 97:804-806.

36. Firehun Y, Struik P, Lantinga E, Taye T: Adaptability of two weevils (Neochetina bruchi and Neochetina eichhorniae) with potential to control water hyacinth in the Rift Valley of Ethiopia. Crop Protection 2015, 76:75-82.

37. Waipara N, Bourdôt G, Hurrell G: Sclerotinia sclerotiorum shows potential for controlling water lettuce, alligator weed and wandering jew. New Zealand Plant Protection 2006, 59:23-27.

38. El-Morsy E: Evaluation of microfungi for the biological control of water hyacinth in Egypt. Fungal Divers 2004, 16:35-51.

39. Williams AE, Hecky RE, Duthie HC: Water hyacinth decline across Lake Victoria was it caused by climatic perturbation or biological control? A reply. Aquatic Botany 2007, 87:94-96.

40. Venter N, Hill MP, Hutchinson SL, Ripley BS: Weevil borne microbes contribute as much to the reduction of photosynthesis in water hyacinth as does herbivory. Biological Control 2013, 64:138-142. 